Wojciech Engelking

\title{
Carla Schmitta krytyka liberalizmu w latach 1916-1938. Próba syntezy i interpretacji
}

\section{UWAGI WSTĘPNE}

Spuścizna Carla Schmitta (1888-1985) jest bogata i różnorodna; czytelnik znajdzie w niej zarówno teksty, które można by zaliczyć do teorii polityki, takie, które są owocem namysłu nad filozofią prawa, jak również prace filologiczne. Gdyby jednak postarać się odszukać w całej twórczości Schmitta jedną powracającą kwestię, która spajałaby dzieła tak tematycznie i stylistycznie różne, jak analiza artykułu 48. konstytucji republiki weimarskiej, teksty dotyczące teologicznego zakorzenienia pojęć politycznych czy esej na temat Szekspira - byłaby to, jak twierdzi Reinhard Mehring, krytyka liberalizmu ${ }^{1}$. Niezależnie od przemian myśli Schmitta, liberalizm jako polityczna idea i pozytywizm prawniczy (z koronnym przykładem w postaci normatywistycznej myśli Hansa Kelsena; to utożsamienie - zarówno w myśli Schmitta, jak i w historii rozwoju niemieckiego namysłu nad polityką - zostanie wyjaśnione niżej) jako jego prawna konsekwencja są dla myśliciela z Plettenbergu głównym przedmiotem ataku. Oczywiście, atak ten inaczej wyglądał w pierwszym z wyszczególnionych przez Mariana Crocego i Andreę Salvatore etapów myśli Schmitta po I Wojnie Światowej, kiedy to zajmował się on problemem legitymizacji i suwerenności z egzystencjalnego punktu widzenia (1922-1933), inaczej zaś w drugim (1934-1936), w którym większy nacisk kładł na kwestie prawne i z pozycji decyzjonistycznej zwracał się w stronę

${ }^{1}$ R. Mehring, Liberalism as a "Metaphysical System". The Methodological Structure of Carl Schmitt's Critique of Political Rationalism, [w:] D. Dyzenhaus (red.), Law as Politics. Carl Schmitt's Critique of Liberalism, Durham-London 1998, s. 134. 
instytucjonalizmu inspirowanego myślą Maurice'a Hauriou². Bardzo różne też są jego dzisiejsze odczytania i nie bez znaczenia jest dla nich polityczna proweniencja odczytującego, gdyż diagnozy Schmitta do krytyki dzisiejszego liberalizmu chętnie wykorzystywali i wykorzystują myśliciele zarówno lewicowi, jak konserwatywni. Chantal Mouffe na przykład twierdzi, że myśliciel z Plettenbergu skupia się w swoich anatemach przeciw liberalizmowi na pokazaniu instrumentalnego charakteru instytucji liberalnej demokracji, podczas gdy Joseph Cropsey uważa, że w myśli Schmitta liberalizm jest, wraz z komunizmem, współwinny obumierania polityczności i zastępowaniu jej przez technologię - sam w sobie nie będąc tak istotnym, jak mogłoby się na pozór wydawać. Tę mnogość możliwych interpretacji przeprowadzonej przez Schmitta krytyki liberalizmu dobrze podsumowuje Gopal Balakrishnan, pisząc, że celem Schmittiańskiego ataku nigdy nie był liberalizm klasyczny, ale raczej pewne nurty, które na jego ciele narosły, niejednokrotnie wynaturzając liberalne idee ${ }^{4}$.

Takim nurtem jest na przykład liberalizm niemiecki, który z klasycznym, anglosaskim liberalizmem nie ma wiele wspólnego. By ukazać problemy związane z rozwojem tego prądu politycznego i ideowego w XIX stuleciu na ziemiach niemieckich, Hubert Orłowski przywołuje pojęcie Sonderweg - drogi szczególnej, której znakiem rozpoznawczym jest „odbiegająca od europejskich struktur demokratycznych swoista nieregularność w kształtowaniu państwowości i »wykluwaniu się« narodu"s. Ponieważ w Niemczech nigdy nie doszło do takiego zwycięstwa nad instytucją monarchii, jak Chwalebna Rewolucja w Anglii czy Wielka Rewolucja Francuska, nie został tam stworzony dokument taki, jak amerykańska Deklaracja Niepodległości, niemiecki liberalizm powstawał w oderwaniu od politycznych uwarunkowań, które sprzyjały jego narodzinom w zachodniej Europie. I choć nie można zgodzić się ze stwierdzeniem Ludwiga von Misesa, jakoby

żaden Niemiec nie miał wkładu w opracowanie wielkiego systemu myśli liberalnej (...). Filozofowie, ekonomiści i socjologowie, którzy rozwijali tę myśl, pisali w języku angielskim i francuskim. W XVIII stuleciu Niemcy nie mieli nawet dobrych thumaczeń dzieł tych angielskich, szkockich i francuskich autorów ${ }^{6}$,

2 M. Croce, A. Salvatore, The Legal Theory of Carl Schmitt, New York 2010, s. 13.

${ }^{3}$ Ch. Mouffe, Polityczność, przeł. J. Erbel, wstęp M. Gdula, Warszawa 2008, s. 120; J. Cropsey, Foreword, [w:] H. Meier, Carl Schmitt and Leo Strauss: The Hidden Dialogue, przeł. J. Harvey Lomax, Chicago 1995, s. x.

${ }^{4}$ Zob.: G. Balakrishnan, The Enemy. An Intellectual Portrait of Carl Schmitt, London 2000, s. 68.

${ }^{5}$ H. Orłowski, Spory o Sonderweg, o niemieckq „drogę odrębna”, [w:] Sonderweg. Spory o niemiecka ,,drogę odrębną”, Poznań 2008, s. 24.

${ }^{6}$ L. von Mises, Omnipotent Government. The Rise of the Total State and Total War, Indianopolis 2011, s. 24-25. 
to należy nadmienić, iż to właśnie niepowodzenie polityczne liberałów w roku 1848 doprowadziło - jak pisał György Lukács - do przedłożenia militarystycznej jedności narodowej nad naczelną liberalną ideę - wolność - i trwałego osadzenia prawa w filozoficzno-politycznym sporze, co Lukács uznawał za znak rozpoznawczy niemieckich liberałów?

Tego przykładem jest najpoważniejsze dokonanie XIX-wiecznych niemieckich liberałów, czyli spopularyzowana m.in. przez Roberta von Mohla koncepcja państwa prawnego, Rechtsstaat (piszę o spopularyzowaniu, gdyż jej pierwszych jaskółek można spodziewać się już pod koniec XVIII stulecia). Niechętny idei prawa naturalnego von Mohl - profesor prawa publicznego z Tybingi, którego pozbawiono katedry za zbyt liberalne poglądy - w powstałej na początku lat 30 . XIX stulecia pracy „Nauka policji zgodnie z zasadami państwa prawnego” zaproponował przeciwstawienie państwa absolutystycznego czy teokratycznego opartemu na regulacjach prawnych państwu liberalnemu, którego głównym celem jest zagwarantowanie obywatelowi wolności i stworzenie wspólnoty; mocno „protestował przeciw ograniczaniu roli państwa do funkcji stróża nocnego, uważał, że obywatele mają prawo żądać od państwa odpowiednich działań; (...) państwo prawne miało być państwem wspomagającym jednostki i społeczeństwo

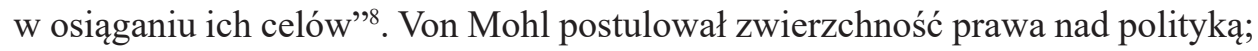
wtórował mu w II połowie XIX wieku Friedriech von Stahl, uważający prawo za rozkaz państwa i twierdzący, że „także rozkaz państwa, który stoi w sprzeczności z rozkazem boskim, nie jest bezprawny" . Nie wchodząc w takie rozwinięcia koncepcji liberalnego państwa prawa, jak socjalny liberalizm von Steina czy ordoliberalizmy Euckena albo Röpkego, można za Chrisem Thornhillem powiedzieć, że mohlowskie i stahlowskie, przygotowujące grunt pod prawniczy pozytywizm sposoby myślenia zostały chętnie przyjęte przez niemieckich liberałów, którzy uznali ideę państwa jako jedynego źródła prawa, wolnego od nie-pozytywnych wartości ${ }^{10}$. Taki właśnie niemiecki liberalizm wyznaczył ideowy klimat późnego Kaiserreich i pierwszych lat Republiki Weimarskiej, czyli czasów, w których Schmitt studiował prawo i rozpoczynał swoją działalność naukową. Oczywiście, bywał wówczas atakowany - przez myślicieli takich, jak Rudolf Smend, Heinrich Triepel, Erich Kaufman czy Hermann Heller - lecz jego idee miały politycznie największą moc sprawczą. Najdobitniejszym tego dowodem mógłby być dokument, który miał wyznaczać nową drogę post-cesarskich Niemiec: uchwalona

${ }^{7}$ G. Lukacs, O niektórych osobliwościach historycznego rozwoju Niemiec, przeł. J. Kałążny, [w:] Sonderweg..., op.cit., s. 220-221.

${ }^{8}$ M. Zmierczak, Ksztaltowanie się koncepcji państwa prawnego (na przykładzie niemieckiej myśli polityczno-prawnej, [w:] J. Kowalski (red.), Państwo prawa, Warszawa 2008, s. 188.

${ }^{9}$ Ibidem, s. 200.

${ }^{10}$ C. Thornhill, Political Theory in Modern Germany: An Introduction, Cambridge 2000, s. 17. 
w roku 1919 konstytucja republiki weimarskiej autorstwa liberalnego prawnika Hugona Preussa, najbardziej wówczas liberalna konstytucja w Europie. Polityczne wpływy myśli Schmitta ograniczały się jednak do teorii, ponieważ - jak pisze cytowany już Gopal Balakrishnan - ,jeszcze przed wojną [która doprowadziła do zniesienia cesarstwa, a zatem umożliwiła także polityczną realizację liberalizmu - WE] hegemonia liberalnego pozytywizmu zaczęła się sypać"11. Podczas czternastu lat, jakie nastąpiły po uchwaleniu konstytucji republiki weimarskiej, liberalny pozytywizm stopniowo tracił moc, do czego Carl Schmitt przyczynił się swoimi pracami i refleksją nad prawem.

Przed II wojną światową autor „Teologii politycznej”przebył drogę od skromnego Privatdozenta na uniwersytecie w Strasbourgu, specjalizującego się w prawie karnym do prominentnego teoretyka prawa, którego lokalna gazeta z Kolonii obdarzyła tytułem koronnego jurysty III Rzeszy ${ }^{12}$. Sposób, w jaki Schmitt krytykował wówczas liberalizm, zmieniał się: czytelnik pierwszej poważnej anatemy - filologicznej z ducha analizy poematu Theodora Däublera „Nordlicht” - łatwo zauważy jego publicystyczny zapał, którego próżno szukać w pochodzącym z 1934 r. artykule „O trzech rodzajach myślenia w nauce prawa”. Późniejsze, powstałe po II wojnie światowej prace Schmitta nie będą tu omówione. Chociaż interesujące ze względu na namysł filozofa z Plettenbergu nad rodzącym się liberalnym porządkiem nowego ius publicum europaeum, są one bogatsze o doświadczenie tego wszystkiego, do czego upadek niemieckiego liberalizmu na początku lat 30. doprowadził.

Krytyka, której Schmitt poddaje liberalizm - choć za każdym razem krytykuje go z innej pozycji - krąży wokół kilku tematów, które łączą się ze sobą i przeplatają. Są to: kwestia neutralizacji i apolityzacji sfery politycznej, która jest liberalizmu konsekwencją, problem stechnicyzowania i zekonomizowania życia umysłowego Zachodu, które się z liberalizmu biorą, wreszcie problem prawa liberalny z ducha pozytywizm prawniczy jako bezsilny wobec nieprzewidzianych wydarzeń i kwestii stanu wyjątkowego, a także krytyka, jakiej Schmitt poddał myśl Hansa Kelsena. Jak twierdzi Franciszek Ryszka, Schmitt niezależnie, czy pisał o dramatach Szekspira, czy o Josephie de Maistrze - poszukiwał właśnie „nowoczesnego sensu prawa, jak ongiś - wiele stuleci wcześniej rozumieli taką konieczność nowożytni legiści"13.

${ }^{11}$ G. Balakrishnan, The Enemy, op.cit., s. 88. John Rawls dodawał z kolei, że za porażkę Weimaru winne są niemieckie elity, które co prawda wydały liberalną konstytucję, ale nigdy w zaistnienie możliwości liberalizmu w Niemczech tak naprawdę nie uwierzyły. J. Rawls, Political Liberalism, New York 2005, s. lix.

12 Zob.: R. Mehring, Carl Schmitt. A Biography, przeł. D. Steuer, Cambridge 2014, s. 543-545.

${ }^{13}$ F. Ryszka, Carl Schmitt w nauce prawa i polityki XX wieku. Twórca i dzieło. Szkic do portretu i wybrane watki teorii, „Studia nad Faszyzmem i Zbrodniami Hitlerowskimi” 1996, t. XIX, s. 11. 


\section{LIBERALIZM JAKO NURT NEUTRALIZACYJNY}

W opublikowanej tuż po II wojnie światowej pracy o klęsce niemieckiego liberalizmu John Hallowell twierdzi, że wynikała ona z upadku wiary w transcendencję, ku której nigdy nie wzniosły się w Niemczech proklamowane przez liberałów obiektywne normy prawa pozytywnego. Innymi słowy, prawo pozytywne nigdy nie stało się na ziemiach niemieckich świętością. Hallowell pisze:

Gdy ludzie porzucili wiarę w transcendentne reguły, a idea obiektywnej prawdy została zniszczona - liberalizm zdegenerował się. Dopóki jednak ludzie wierzyli w obiektywną prawdę i poza-jednostkowe wartości (...) liberalizm zachowywał swoją integralność.

Kiedy przestał ją zachowywać, wymuszenie przestrzegania prawa, twierdzi Hallowell, stało się możliwe wyłącznie dzięki zastosowaniu przemocy ${ }^{14}$.

Analiza Hallowella wiele czerpie z dzieła młodego Schmitta. Co angielskiego badacza od autora „Teologii politycznej” odróżnia, to moment, na którym się skupiają. Dla autora eseju na temat poematu Theodora Däublera „Nordlicht” interesująca jest bowiem nie chwila, w której przemoc zostaje zastosowana, ale ta, która ją poprzedza, czyli ta, w której liberalizm traci swoją integralność i społeczeństwo $\mathrm{z}$ wolna pogrąża się $\mathrm{w}$ antynomicznym chaosie. $\mathrm{W}$ trzecim rozdziale pracy na temat poematu Däublera Schmitt odsuwa na bok filologiczną analizę, by przedstawić mocną krytykę swoich czasów. Pisze o nich, że

ludzie stali się biednymi diabłami; ,wszystko wiedzą, ale w nic nie wierzą”. Interesuje ich wszystko, nic jednak nie pasjonuje. Wszystko, co rozumieją, rozumieją dlatego, że ich uczeni zarejestrowali to w historii, w naturze, we własnej duszy. Są znawcami bliźnich, psychologami i socjologami, piszą nawet socjologię socjologii. (...) Z więzienia duszy świat stał się dla niej przytulną letnią rezydencją ${ }^{15}$.

Ludzie, według dwudziestoośmioletniego Schmitta, pragną stworzyć na ziemi niebo, które byłoby rezultatem działalności handlowej i przemysłowej, prawdziwego nieba jednak nie chcą, podobnie jak „nie pragną Boga miłości i łaski” ${ }^{16}$. Liberalny świat to, według Schmitta, świat przede wszystkim zeświecczony, który przeszedł sekularyzację i w którym „Pan Bóg jest rekwizytem przydatnym dla wiersza” jak o świecie w roku poprzedzającym I wojnę światową pisał pewien inny wielki krytyk nowoczesności ${ }^{17}$. Powstaje jednak pytanie: kiedy właściwie ten liberalny

14 J. Hallowell, The Decline of Liberalism as Ideology, London 1946, s. 10.

${ }_{15}$ C. Schmitt, Theodor Däublers „Nordlicht”: drei Studien Drei Studien über die Elemente, den Geist und die Aktualität des Werkes, cyt. za: H. Meier, The Lesson of Carl Schmitt: Four Chapters on the Distinction between Political Theology and Political Philosophy, Chicago 2011, s. 3.

${ }^{16}$ Ibidem, s. 4.

${ }^{17}$ H. Broch, Gtosy 1913, [w:] idem, Lunatycy, przeł. W. Wirpsza, Wrocław 2005, s. 543. 
proces się rozpoczął? Kto go zapoczątkował, kto ponosi winę za to, że świat jest pozbawiony transcendencji, a sfera polityczności została zneutralizowana?

$\mathrm{Na}$ to pytanie nie znajdziemy odpowiedzi w pracy na temat poematu Däublera, trzeba po nią sięgnąć do późniejszej pracy Schmitta, o wiele bardziej zagadkowej, czyli napisanego w roku 1938 ,Lewiatana w teorii państwa Tomasza Hobbesa". Uderzająca jest w tej krótkiej książce odwaga Schmitta w apologii (ostatnie jej słowa brzmią: „Ponad stuleciami wołamy do niego: Non iam frustra doces, Thomas Hobbes!"18) angielskiego filozofa, powszechnie uważanego za protoliberała i twórcę rozdzielenia sfery publicznej od prywatnej i fides od confessio. Najpowszechniejsza interpretacja myśl Hobbesa to przecież ta, wedle której w państwie Lewiatana „obywatele mogą wierzyć w to, co chcą, palić świece przed dowolnym bóstwem, ale tylko w domu, najlepiej za firanką. Natomiast publicznie mają uczestniczyć w kulcie zorganizowanym, zewnętrznym"19. Schmitt się z takim podejściem nie zgadza i broni reputacji autora „Lewiatana”, przeciwstawiając mu innego XVII-wiecznego myśliciela - Barucha Spinozę. Twierdzi, że to właśnie

Żyd Spinoza odpowiada za przygotowanie filozoficznych podstaw liberalizmu. (...) Jego próba uczynienia z religii całkowicie prywatnej sprawy była pierwszą z serii historycznych neutralizacji, które doprowadziły do tego, że indywidualnemu podmiotowi dozwolono determinowanie swoich politycznych obligacji pod kątem własnego, indywidualnego interesu ${ }^{20}$.

Jednym słowem, liberalna sekularyzacja, która zaczyna się dla Schmitta wraz ze Spinozą, oznacza nie tyle wyrugowanie religii ze sfery publicznej i zaprzeczenie zasadzie cuius regio, eius religio, ile coś poważniejszego: pozbawienie chrześcijaństwa (czy, wąsko rzecz ujmując, także ze względu na identyfikację religijną samego Schmitta - katolicyzmu) politycznej i prawnej mocy. W świecie po tej sekularyzacji

prawo staje się siłą; lojalność - obliczalnością; prawda - poprawnością; chrześcijanie - grupą pacyfistów. Na miejsce rozróżnienia między dobrem i złem pojawia się rozróżnienie między opłacalnością a nieopłacalnością ${ }^{21}$.

Dlaczego dla piszącego swoją analizę Däublera (i kilka innych tekstów z lat 10. i 20. XX wieku) z perspektywy młodego katolika Schmitta stojące w opozycji do liberalizmu chrześcijaństwo jest tak istotne? W czym liberalizm jest odeń

${ }^{18}$ C. Schmitt, Lewiatan $w$ teorii państwa Thomasa Hobbesa: sens i niepowodzenie politycznego symbolu, przeł. M. Falkowski, Warszawa 2008, s. 158.

19 P. Nowak, Metamorfozy potwora, [w:] idem, Podpis księcia. Rozważania o mocy i słabości, Warszawa 2013, s. 141.

${ }^{20}$ G. Balakrishnan, The Enemy, op.cit., s. 217.

${ }^{21}$ C. Schmitt, Theodor Däublers „,Nordlicht”..., op.cit., s. 4. 
gorszy i dlaczego doprowadza on do zneutralizowana sfery politycznej, a chrześcijaństwo nie?

Zdaniem Schmitta jedynie chrześcijaństwo ma polityczną siłę, która w Europie mogła stać się mitem. Mit zaś, jak pisze Carsten Strathausen,

jest dla Schmitta zdehistoryzowanym i niezaprzeczalnym rdzeniem ludzkiej wiedzy. Jest od wiedzy silniejszy, nie tylko dlatego, że jego siła oddziaływania jest intuicyjna raczej niż intelektualna, ale głównie dlatego, że nie można mu zaprzeczyć, jest poza kategoriami: prawdafałsz ${ }^{22}$.

Objawieniu nie można zaprzeczyć ani go potwierdzić: objawienie po prostu jest i z jego wartościami się nie dyskutuje. Tymczasem w świetle ideologii liberalnej, rządzącej się prawami rynkowej opłacalności i techniki, każde ludzkie, polityczne, działanie może zostać ocenione z ekonomicznego punktu widzenia jako sukces lub porażka. Ekonomiczny sukces nie może stać się jednak życiodajnym, politycznym mitem, który w sferze polityczności wprowadziłby rozróżnienie na to, kto jest przyjacielem, a kto wrogiem. Liczy się to, co jest opłacalne, a to, co jest opłacalne, jest politycznie obojętne. Nie chodzi o to, że sfera polityczności w wyniku naporu ideologii liberalnej znika - znika raczej, jak twierdzi w komentarzu do „Pojęcia polityczności” Schmitta Leo Strauss, jej rozumienie. Zdaniem Schmitta - pisze Strauss - ,przyczyny upadku liberalizmu są następujące: liberalizm negował polityczność, jednak nie usunął jej, tylko schował, doprowadzając tym samym do prowadzenia polityki metodami antypolitycznymi"’33. Kiedy zaś znika rozumienie polityczności, następuje liberalna epoka neutralizacji i apolityzacji - jak Schmitt zatytułował napisany w 1929 roku (dziesięć lat po analizie poematu Däublera) esej.

Esej ów był pierwotnie wygłoszonym w Hiszpanii wykładem; myśliciel z Plettenbergu wprowadza w nim pojęcie „obszaru centralnego”. Pisze Schmitt: „W ostatnich czterech stuleciach historii Europy życie duchowe miało cztery rozmaite centra, a myślenie aktywnych elit, tworzących awangardę danej epoki, poruszało się w kolejnych stuleciach wokół rozmaitych punktów środkowych”24. Obszar centralny, według niego, definiuje dla danej epoki i nadaje polityczną moc kluczowym dla europejskiego ducha pojęciom, takim jak Bóg, wolność czy postęp. „Wszystko to zawiera konkretną historyczną treść ze względu na położenie

${ }^{22}$ C. Strathausen, Myth or Knowledge? Reading Carl Schmitt's „Hamlet or Hecuba”, „Télos” 2010 (153), s. 22.

${ }^{23}$ L. Strauss, Notes on Carl Schmitt, ,, The Concept of the Political”, przeł. J.H. Lomax, [w:] C. Schmitt, The Concept of the Political: Expanded Edition, przeł. G. Schwab, Chicago-London 2007, s. $100-101$.

${ }^{24}$ C. Schmitt, Epoka neutralizacji i apolityzacji, thum. W. Kunicki, [w:] W. Kunicki (red.), Rewolucja konserwatywna w Niemczech 1918-1933, Poznań 1999, s. 429. 
obszaru centralnego i tylko z jego perspektywy powinno się je pojmować" ${ }^{25}$. Przez ostatnie cztery stulecia - czyli jeszcze przed czasami liberalnego Spinozy - następował, wedle Schmitta, stopniowy odwrót od wypełnienia w Europie obszaru centralnego przez chrześcijańskiego Boga: najpierw sfera teologiczna przerodziła się w metafizyczną, by następnie stać się sferą humanitarno-moralną, a potem - ekonomiczną. Autor „Pojęcia polityczności” twierdzi, że od XVI stulecia europejski liberalizm szukał przestrzeni, w której można osiągnąć kompromis i wyrugować konflikt. Istotne znaczenie w tym procesie Schmitt przypisuje romantyzmowi, który krytykował już w analizie poematu Däublera; dopiero jednak w „Epoce neutralizacji i apolityzacji” krytyka ta wybrzmiewa z odpowiednią mocą, ponieważ to w tym eseju Schmitt stwierdza, że właśnie romantyzm ze swoim estetyzmem zapewnił łatwe i wygodne przejście od humanitarno-moralnego oświecenia do ekonomizmu i kultu technologii jego czasów ${ }^{26}$. Co jednak istotne, Schmitt - jako konserwatysta w stylu Josepha de Maistre'a - nie wierzy w możliwość powrotu do czasów sprzed apolitycznego, liberalnego państwa agnostycznego: liberalizm wygrał i ostatecznie zneutralizował sferę polityczności. Jedyne, co teraz można robić, to walczyć ze skutkami tego zwycięstwa, z całą sferą „nierzeczywistości”, jaką jest dla konserwatysty świat po zwycięstwie liberalizmu.

Nierzeczywistość to jedno z kluczowych pojęć niemieckiej krytyki kultury z lat 20. i 30. XX wieku, niezależnie od politycznych proweniencji danego krytyka: chętnie posługiwali się nim zarówno Tomasz Mann, jak Oswald Spengler czy Ernst Jünger, którzy w obliczu nagłych przemian cywilizacyjnych i wzrostu roli technologii zaczęli traktować zastany świat jako rodzaj nierzeczywistości ${ }^{27}$. O ile w przypadku liberalnych i lewicowych krytyków nowoczesności mogło się to łatwo przerodzić w rewolucyjne działanie polityczne, o tyle w przypadku z zasady zachowawczych konserwatystów już nie. Rewolucyjni konserwatyści tamtego czasu byli więc konserwatystami „wydziedziczonymi, niemającymi czego zachowywać, bowiem wartości duchowe przeszłej epoki zostały pogrzebane"28. Carl Schmitt nad którego wpisaniem w nurt rewolucyjnego konserwatyzmu długo trwały spory ${ }^{29}$ - wychodzi z dylematu konserwatysty postawionego w nierzeczywistości politycznej obronną ręką; otóż postanawia odnaleźć w samej politycznej koncepcji liberalnej demokracji takie elementy, które by sobie przeczyły. Innymi

${ }^{25}$ Ibidem, s. 430.

${ }^{26}$ Por.: J.P. McCormick, Carl Schmitt's Critique of Liberalism, op.cit., ss. 44, 65.

${ }^{27}$ Zob.: R. Skarzyński, Konserwatyzm. Zarys dziejów filozofii politycznej, Warszawa 1998, s. 123 .

${ }^{28}$ F. Stern, The Politics of Cultural Despair. A Study in the Rise of the German Ideology, Berkeley 1961, s. xvi.

${ }^{29}$ Por. np.: F. Ryszka, Intelektualiści a hitleryzm. Szkic o rewolucji konserwatywnej w Niemczech, „Kwartalnik Historyczny” 1959, r. LXVI, nr 2. 
słowy: prowadzić w warunkach liberalnych obronę demokracji wbrew i przeciw liberalizmowi.

Koronne przykłady takiego myślenia Schmitta niosą pochodząca z 1932 roku książka „Legalność i prawomocność” i o trzy lata wcześniejsza „Nauka o konstytucji”. Obie te prace Michael G. Salter uznaje za Schmittiańską „obronę demokratycznej formy rządu konstytucyjnego" ${ }^{30}$. Według Schmitta, to, czym liberalizm postanowił wypełnić pustkę po micie, jaka powstała wraz z utratą politycznej siły przez chrześcijaństwo, zabiło demokratyczne ideały, które przyświecały mu w wypełnianiu tej pustki. Weźmy na przykład proces głosowania, który w swojej tajności „przeobraża obywatela w izolowaną jednostkę prywatną i umożliwia mu wyrażanie opinii bez porzucania sfery prywatnej”. Członek narodu ujętego w formę liberalno-demokratyczną, choć z pozoru cały czas swoją decyzją - głosem oddanym przy urnie - stanowi polityczną wolę takiego narodu, w istocie wcale jej nie stanowi, ponieważ za jego decyzją nie idzie publiczno-polityczna odpowiedzialność: głosowanie pozostaje, po spinoziańsku, procesem prywatnym. Konsekwencją ustroju opierającego się na tego rodzaju mechanizmach jest rozmycie formy państwowej przez jej zneutralizowanie, czyli zniszczenie rozumienia polityczności.

Wedle Schmitta, każda forma państwowa opiera się na pewnego rodzaju micie, który wypełnia obszar centralny danej epoki, wpływając na rozumienie kluczowychdla niej pojęć. Do XVI wieku mitem tym była niepozbawiona politycznej siły religia chrześcijańska. W wieku XVII, za sprawą myślicieli takich jak Baruch Spinoza, w Europie nastąpił odwrót od traktowania chrześcijaństwa jako wypełnienia obszaru centralnego i ześwieczczenie sfery politycznej, a właściwie - ześwieczczenie jej rozumienia i jego stopniowa neutralizacja. W wieku XX na miejsce dawniej zajmowane przez chrześcijaństwo wszedł bowiem przedmiot zupełnie innej religii, religii postępu: technika. „XX wiek - pisze Schmitt - jawi się już u swych początków jako epoka nie tylko techniki, ale także religijnej wiary w technikę"31.

\section{LIBERALIZM JAKO RELIGIA TECHNIKI}

Krytyka techniki i religijnego jej traktowania nie była w czasach Schmitta niczym nowym. Technika była wszak dzieckiem pozytywizmu, który Eric Voegelin uznawał za nowożytną formę religijnej gnozy ${ }^{32}$. Podobnie w 1944 roku rozu-

${ }^{30}$ M.G. Salter, Carl Schmitt. Law as Politics, Ideology and Strategic Myth, London-New York 2012, s. 176.

${ }^{31}$ C. Schmitt, Epoka..., op.cit., s. 432.

32 E. Voegelin, Nowa nauka polityki, przeł. P. Śpiewak, Warszawa 1992, s. 107. 
mowali Max Horkheimer i Teodor W. Adorno, twierdząc, że technika jest istotą oświeceniowej wiedzy, która „nie zmierza do wykształcenia pojęć ni obrazów, nie przyświeca jej szczęście poznania, jej celem jest metoda, wykorzystanie cudzej pracy, kapitał”, a otaczający ją nimb religijnego kultu to przykład „regresu oświecenia w mitologię, którego szukać należy (...) w samym oświeceniu, gdy zastyga ono w lęku przed prawdą"33. Co w takim razie nowego ma czytelnikowi do zaproponowania autor „Teologii politycznej” - oprócz oczywistego spostrzeżenia, że napór ideologii liberalnej jest jedną z przyczyn takiego traktowania techniki? Najkrócej rzecz ujmując: analizę tego, jak ów kult wpływa na myślenie o polityce i aktywność polityczną w świecie, w którym rozumienie polityczności jest powoli niszczone, ponieważ technika - jak ujmuje to Schmitt w „Epoce neutralizacji i apolityzacji" - walczy z polityką i prawem ${ }^{34}$.

Technika - warto zauważyć - nie jest w tej walce li tylko orężem liberałów. Za równie potężne jak ideologia liberalna zagrożenie dla polityczności w $1929 \mathrm{r}$. Schmitt uznaje bowiem także inny organizm (anty)polityczny: bolszewicki Związek Radziecki, w którym, jak twierdzi, obowiązuje ten sam sposób myślenia, co na kapitalistyczno-liberalnym zachodzie. Pisze:

Wielkiemu przedsiębiorcy przyświeca ten sam cel, co Leninowi: - ,zelektryfikowana Ziemia”. Spór między nimi dotyczy jedynie właściwej metody przeprowadzenia elektryfikacjii ${ }^{35}$.

O ile jednak w uznanej przez Schmitta za obowiązującą w bolszewickiej Rosji myśli marksistowskiej podstawą rozwoju społecznego pozostaje konflikt, a rewolucyjna przemoc i wojna domowa nie zostaje wyrugowana ze sfery polityczności, o tyle w świecie opanowanym przez myśl liberalną postępuje stopniowa neutralizacja i apolityzacja sfery politycznej ${ }^{36}$. Wspólnego punktu między tymi dwoma (anty)politycznymi organizmami trzeba zatem szukać gdzie indziej: zdaniem Schmitta tym, co liberałów i marksistowskich bolszewików łączy, to przekonanie o technicznym charakterze polityki. Dla liberałów, twierdzi, technika jest tak neutralna, że może im się wydawać sferą ,pokoju, porozumienia i pojednania" ${ }^{37}$ : uprawianie więc polityki za pomocą techniki oznacza rozszerzanie tej sfery na całość życia społecznego. W myśli marksistowskiej dominuje przekonanie, że konflikt, który jest podstawą życia społecznego, rozwiąże się sam, w ramach tech-

${ }_{33}$ M. Horkheimer, T.W. Adorno, Dialektyka oświecenia, przeł. M. Łukasiewicz, posłowie M.J. Siemek, Warszawa 2012, s. 11-16.

${ }^{34}$ C. Schmitt, Epoka ..., op.cit., s. 400.

${ }^{35}$ C. Schmitt, Rzymski katolicyzm i polityczna forma, [w:] idem, Teologia polityczna i inne pisma, przeł. M.A. Cichocki, Warszawa 2012, s. 115.

${ }^{36}$ Por.: idem, Teoria partyzanta. Uwagi na marginesie „Pojęcia polityczności”, przeł. B. Cymbrowski, Warszawa 2016, s. 64.

37 Idem, Epoka..., op.cit., s. 439. 
nicznego procesu walki klas. Takie postawienie sprawy i przez liberałów, i marksistów jest dla Schmitta, po nietzscheańsku, oznaką wiary człowieka we własną nieograniczoną moc i panowanie nad naturą. Rozumując teologicznie, myśliciel z Plettenbergu wiarę ową nazywa w „Epoce neutralizacji i apolityzacji” „duchem złym i szatańskim"38. Rozumując politycznie z kolei, w ramach wspomnianej wyżej krytyki nierzeczywistości - Schmitt wskazuje na zagrożenia, jakie niesie za sobą liberalna koncepcja neutralności państwa, w którym technika otoczona jest para-religijnym kultem.

W tym miejscu warto wrócić do opisywanej wyżej, Schmittiańskiej teorii „obszaru centralnego" i przypomnieć, jaki nie-mit poprzedzał traktowaną na sposób religijny technikę. Według Schmitta, w XIX stuleciu tym nie-mitem była sfera ekonomicznej i gospodarczej działalności państwa, którą myśliciel z Plettenbergu rozumie pod terminem Wirtschaft - na sposób weberowski, bo jako organizację wewnętrznych spraw społecznych i działalności międzyludzkiej ${ }^{39}$. Dominantą XIX-wiecznego myślenia ekonomicznego, twierdzi, jest przemienienie aktywnego w sferze politycznej obywatela w producenta, który w politycznie sprawczą masę grupuje się wedle indywidualnego interesu gospodarczego, co w procesie demokratycznych wyborów doprowadza do osłabienia jedności państwa. „Gospodarcze i społeczne przeciwieństwa - pisze Schmitt - nie zostają dzięki temu rozwiązane, okazując się jeszcze bardziej bezwzględnymi, gdyż zwalczające się wzajemnie grupy nie są w stanie doprowadzić do faktycznych wyborów powszechnych i reprezentować narodu"40. Jedynym ratunkiem przeciwko takiemu procesowi, zdaniem Schmitta, jest oddanie państwu kontroli nad gospodarką i ekonomią. Jest - a właściwie było, dopóki to właśnie ekonomia i gospodarka jako Wirtschaft stanowiły nie-mit wypełniający obszar centralny. Kiedy Schmitt pisał swój tekst, sprawa zrobiła się bardziej skomplikowana, ponieważ zacierające różnicę między państwem a społeczeństwem miejsce gospodarki zajęła technika, która, niszcząc rozumienie polityczności, uczyniła państwo wewnątrzpolitycznie neutralnym. W tym miejscu dochodzimy do Schmittiańskiej krytyki demokracji parlamentarnej - bodaj najbardziej publicystycznego elementu jego myśli, którego nie sposób oddzielić od tego, co działo się w wówczas w Weimarze.

${ }^{38}$ Ibidem, s. 432. Schmitt mógłby zapewne powtórzyć za Nietzschem, że „hybris jest dziś nasz stosunek do natury, nasze pogwałcenie natury z pomocą machin i tak beztroskiej wynalazczości techników i inżynierów". F. Nietzsche, Z genealogii moralności. Pisma polemiczne, przeł. L. Staff, Warszawa 1904, s. 134.

39 Zob.: J. McCormick, Carl Schmitt's Critique of Liberalism ..., op.cit., s. 100.

${ }^{40}$ C. Schmitt, Das Problem der innerpolitischen Neutralitat des Staates, cyt. za: M. Lievens, „Carl Schmitt's Metapolitics”, https://irias.kuleuven.be/bitstream/123456789/305582/3/ Carl+Schmitt's+Metapolitics.pdf [dostęp: 07.03. 2017]. 
Republika weimarska pod koniec lat 20. XX stulecia pod względem partyjnego rozbicia przypominała II Rzeczpospolitą: przez zaledwie dwanaście lat jej istnienia u władzy było aż sześć partii. Na ogół koalicja rządząca składała się z trzech: SPD, chadeckiej partii centralnej i DDP. Po 1920 roku dołączyła do nich DVP, niezbędna do uzyskania większości w Reichstagu. Ta, jak ją określił Schmitt, „zmienna koalicja partyjna”, nie była w stanie podjąć jakiejkolwiek doniosłej inicjatywy politycznej, a „kryzys polityczny powodował kryzys administracji i wymiaru sprawiedliwości, który paraliżował państwo"41. W pierwszych latach Weimaru, kiedy państwo musiało zmierzyć się z takimi antysystemowymi wystąpieniami, jak pucz monachijski z roku 1923 czy o trzy lata wcześniejszy pucz Kappa - odkryto rozwiązanie tego problemu w postaci osłabienia legislatywy i wzmocnienia egzekutywy: rządzenie przy użyciu prezydenckich dekretów (pomiędzy 10 października 1919 r. a 31 grudnia 1933 r. władze Rzeszy wydały rekordową ich liczbę - dwieście pięćdziesiąt cztery). Później, kiedy nastąpiły lata gospodarczo dla Weimaru tłuste, to rozwiązanie było kontynuowane - żadnemu rządowi nie udało się bowiem stworzyć gabinetu większościowego i po upadku tego prowadzonego przez Gustava Stresemanna, w latach 1924-1932, prezydent aż sześciokrotnie rozwiązywał Reichstag. Trwanie Rzeszy zostało zatem oparte na prezydencie. Niezależnie od poparcia Schmitta dla tego modelu zarządzania państwem trzeba powiedzieć, że zauważał on samowynaturzenie, do jakiego doprowadził się ustrój liberalny. Schmitt mógłby się zapewne podpisać pod zdaniem wypowiedzianym przez pewnego łotewskiego polityka w roku 1921, który, gdy zaproponowano, by konstytucja bałtyckiego kraju była podobna do niemieckiej, miał stwierdzić:

przykład Niemiec nie jest przekonujący. Teraz prezydentem jest demokrata Ebert, ale gdyby np. na prezydenta wybrany został Hindenburg, to ulotniłaby się nie tylko konstytucja weimarska, lecz i cała republika niemiecka ${ }^{42}$.

I choć Schmitta jako prawnika interesowały sposoby rozwiązania tego kryzysu, jako myśliciela politycznego (o ile można te dwie sfery rozdzielić) - coś innego: to, w jaki sposób do sytuacji, w której państwo jest „,zmienną koalicją partyjną” doprowadził kult techniki, który trafił na podłoże (anty)polityczne liberalnego państwa neutralnego.

Według myśliciela z Plettenbergu w państwie, które jest „teatrem rozgrywki pomiędzy kilkoma wpływowymi grupami, starającymi się zdobyć polityczną

${ }^{41}$ H. Grunwald, Courtroom to Revolutionary Stage: Performance and Ideology in Weimar Political Trials, Oxford 2012, s. 6.

${ }^{42}$ Cyt. za: M. Labijak, Rozwiazania prawnoustrojowe republiki Weimarskiej w perspektywie historycznej i porównawczej, „Studia Iuridica Toruniensia” 2014, t. XIV, s. 182. 
władzę za zasłoną demokratycznych uwarunkowań konstytucyjnych" ${ }^{\text {"33 }}$ substancja polityczna nie tyle nie jest już wyłączną domeną zakładającego pojęcie polityczności państwa, ile ulatnia się z niego, stając się własnością walczących ze sobą o wpływy partii właśnie. Każda z nich ma równe szanse na wygranie wyborów i zdobycie nie całej władzy - to nawet nie jest ich celem - ale miejsca w koalicji, i następnie podzielenia się wpływami i urzędami państwowymi według ustawowej kwoty ${ }^{44}$. Ową szansę Schmitt określa przy użyciu terminu zaczerpniętego z myśli Maxa Webera: chance. Pojęcie to, jak piszą Richard Swedberg i Ola Agevall, ma dwa znaczenia: po pierwsze okazji, po drugie - dającego się obrachować ekonomicznie prawdopodobieństwa ${ }^{45}$. Już sam fakt, że zjawisko polityczne jest określone przy użyciu terminu pochodzącego spoza nauki polityki, sporo mówi o stosunku Schmitta do aktualnej w jego czasach sytuacji parlamentarnej; powie więcej, gdy spojrzymy, jak Schmitt pojęcie chance redefiniuje. Czyni to w „Legalności i prawomocności”, ostatniej swojej poważnej pracy opublikowanej przed upadkiem Republiki Weimarskiej. Chance jest w niej dla Schmitta słowem najlepiej wyrażającym sposób myślenia epoki liberalnej, oznaczającym „mieszaninę szczęśliwego przypadku i legalizmu, wolności i wyrachowania, arbitralności i odpowiedzialności” ${ }^{46}$. Inaczej mówiąc, chance w neutralnym aksjologicznie, liberalnym państwie, w którym miejsce polityczności zajęła technika, jest synonimem jak najsprawniejszego technicznego wykorzystania możliwości danych przez aktualną sytuację. Polityka, miast być starciem między przyjacielem i wrogiem, staje się techniką, czyli umiejętnością dostosowania się danej partii czy grupy interesów do gustów wyborców. Polityka staje się zbieżna z aktywnością partii. Powstaje jednak pytanie: czy takie postawienie sprawy nie umiejscawia Schmitta wśród przeciwników demokracji i pluralizmu, zwolenników państwa totalnego?

Ryszard Skarzyński twierdzi, że Schmittiańska koncepcja stanu wyjątkowego może funkcjonować równie dobrze i w dyktaturze, i w demokracji, a jej twórcę w istocie można uznać za legalistę ${ }^{47}$. Myśliciel z Plettenbergu nie jest krytykiem pluralizmu; pozostając zwolennikiem jedności państwa, posługuje się argumentem św. Tomasza z Akwinu, uznającego jedność za jego główną - tożsamą z po-

\footnotetext{
${ }^{43}$ A. Croce, M. Salvatore, The Legal Theory of Carl Schmitt, op.cit., s. 31.

${ }^{44}$ C. Schmitt, Etyka państwowa a pluralistyczna teoria państwa, [w:] idem, Teologia polityczna, op.cit., s. 244.

${ }^{45}$ R. Swedberg, O. Agevall, The Max Weber Dictionary: Key Words and Central Concepts, Stanford 2005, s. 184.

${ }^{46}$ C. Schmitt, Legalność i prawomocność, op.cit., s. 53. Por.: I.M. Zeitlin, Max Weber's Sociology of Law, „The University of Toronto Law Journal” 1985, Vol. 35, No. 2, s. 210.

${ }^{47}$ Zob.: R. Skarzyński, Od chaosu do ładu. Carl Schmitt i problem tego, co polityczne, Warszawa 1991, s. 14.
} 
kojem - wartość, ale też twierdzącego, że jedność całkowita państwo niszczy ${ }^{48}$. Według Schmitta świat polityczny jest ze swej natury pluralistyczny; problem stanowi „trafne umiejscowienie” pluralizmu w hierarchii wartości sfery politycznej ${ }^{49}$. W państwie liberalnym, a zatem aksjologicznie neutralnym, w którym ta sfera stała się domeną działalności partii politycznych, a polityka stała się synonimem techniki wygrywania wyborów i rządzenia, pluralizm prowadzi do zagrożenia wewnętrznej jedności państwa, gdyż państwo nie jest w stanie określić tego, co jest jego najpełniejszym wyrazem: państwowej woli. Ta może być bowiem każda, dostosowywana do aktualnie przeważającej większości parlamentarnej. Jednościowe państwo w swoim pluralizmie zlewa się zatem ze spluralizowanym społeczeństwem, co z kolei - dzięki chance - prowadzi do niebezpieczeństwa nadużyć, gdy ,jakaś konkretna grupa społeczna zaczyna realizować swoje interesy w imieniu całości i bezzasadnie utożsamia się z całym państwem"50.

Jak jednak wygląda to w praktyce? Oczywiście - sprowadzanie myśli politycznej Schmitta do realnych możliwości realizacji jej rozpoznań i założeń jest spłycaniem jej; warto jednak spojrzeć na konkretne przykłady, w jaki sposób liberalne państwo, w którym polityka stała się techniką, wynaturzyło się, i jak Schmitt proponował, by je naprawić. $\mathrm{W}$ ten sposób dochodzimy do tematu prawa.

\section{SCHMITTA KRYTYKA POZYTYWIZMU (I): PAŃSTWO USTAWODAWCZE I STAN WYJĄTKOWY}

„Postrzegam siebie jako stuprocentowego jurystę i nikogo więcej. I nikim więcej nie chcę być" - powiedział Schmitt w udzielonym w 1983 r. wywiadzie ${ }^{51}$. Jurystę - a więc przedstawiciela nauki prawa, która wraz z dominacją liberalnego pozytywizmu została dotknięta przez ciężki kryzys. Etapy popadania w kryzys są, zdaniem Schmitta, dwa. W pierwszym przyjęte zostaje wynikające z pozytywizmu naukowego metodologiczne założenie, w ramach którego przedmiotem poznania mogą być wyłącznie obserwowalne fakty, w wypadku nauki prawa pozytywne normy ${ }^{52}$. W drugim następuje spostrzeżenie, że normy te mogą zostać bardzo szybko zmienione jedną decyzją legislatywy. Nie są więc faktami naukowymi, zatem jurysprudencja nie może być nauką. W warunkach wynikającego

${ }^{48}$ C. Schmitt, Nauka o konstytucji, przeł. M. Kurkowska, R. Marszałek, red. M.A. Cichocki, T. Krawczyk, Warszawa 2013, s. 233.

49 Ibidem, s. 239.

${ }^{50}$ Idem, Etyka państwowa..., op.cit., s. 241.

${ }^{51}$ Idem, Un giurista davanti a se stesso. Saggi e interviste, Vicenza 1983, cyt. za: M. Croce, A. Salvatore, The Legal Theory of Carl Schmitt, op.cit., s. 2.

${ }^{52}$ Zob.: L.L. Fuller, Anatomia prawa, przeł. R. Tokarczyk, Lublin 1993, s. 167-169. 
z pozytywizmu naukowego liberalnego pozytywizmu prawniczego jurysprudencja degeneruje się, stając ledwie „,sztuką czy też techniką"53.

To, co Schmitta interesuje, to właśnie etap drugi. Czy bowiem degeneracja wynika wyłącznie z porzucenia prawa naturalnego przez ,naszych ojców i dziadków, którzy w przejściu do tzw. »pozytywizmu« widzieli postęp od iluzji do rzeczywistości" ${ }^{54}$ ? Rzecz jasna - nie. Jej bezpośrednim powodem, twierdzi w „Legalności i prawomocności”, jest przemienienie się liberalnego, Mohlowego Rechtstaat w państwo ustawodawcze, Gesetzgebungsstaat, w którym próżno szukać prawdziwej władzy, która byłaby, jak nazywa ją Schmitt, „nagą siłą"55. Teoretycznie bowiem rządzić ma spisana, pozytywna ustawa, która zawiera normy; to oznacza jednak, że władza jest bezosobowa i sprowadza się nie do konkretnych politycznych działań, ale przezroczystego obowiązywania prawa - czystej legalności, która ma oparcie tylko w sobie samej. Schmitt:

Można mówić bez poczucia sprzeczności, że np. rozwiązanie Reichstagu jest „ściśle legalne”, a zarazem stanowi zamach stanu (...) W takich antytezach dokumentuje się zapaść systemu legalności, który przybiera postać formalizmu i funkcjonalizmu bez przedmiotu ani odniesienia. Ostateczny, zasadniczy sens fundamentalnej „zasady zgodności z prawem” całego życia państwowego polega na tym, że w ogóle nie ma już rządzenia ani rozkazywania, gdyż tylko wdraża sie , bezosobowo obowiązujące normy ${ }^{56}$.

Warto w tym miejscu przypomnieć także uwagi poczynione przez Schmitta w pisanym już w trakcie wojny eseju „Die Lage der europäischen Rechtswissenschaft”, w którym krytykuje on legislacyjną nadpobudliwość prawotwórców w czasach Weimaru, którzy znacząco skrócili procedurę ustawodawczą. Wobec sprowadzenia legislatywy do maszyny produkującej kolejne ustawy, dotychczasowi komentatorzy prawa - juryści - nie nadążyli za analizowaniem go i zastąpieni zostali w swoim fachu przez urzędników ${ }^{57}$. Normy stały się ,technicznymi urządzeniami, które stosuje się do rzeczywistości, która nie ma nic wspólnego z rzeczywistością faktyczną" ${ }^{58}$. Te właśnie techniczne, aksjologicznie obojętne i zdepersonalizowane urządzenia miały rządzić Niemcami, od kiedy w XIX stuleciu wykuła się myśl przedstawiona przez Schmitta w następujący sposób: „państwo jest ustawą, ustawa jest państwem".

Problem w tym, że normy zawarte w ustawach rządzić rzeczywistością nie mogą; mogą rządzić najwyżej opisywaną wyżej nierzeczywistością, jako, by

\footnotetext{
${ }^{53}$ C. Schmitt, The Plight of European Jurisprudence, „Télos” Spring 1990, s. 35.

${ }^{54}$ Ibidem, s. 37.

${ }^{55}$ Idem, Legalność i prawomocność, op.cit., s. 64.

56 Ibidem, s. 65.

${ }^{57}$ Idem, The Plight..., op. cit., s. 43.

${ }_{58}$ M. Croce, A. Salvatore, The Legal Theory of Carl Schmitt, op.cit., s. 38.
} 
przywołać sformułowanie z „Legalności i prawomocności”, rodzaj kontrprawa. Założenie liberalnego pozytywizmu, wedle którego prawo pozytywne, niezależne od aktualnych stosunków społecznych, paradoksalnie znakomicie je opisuje i obejmuje każdy ich aspekt, jest dla Schmitta o tyle nie do przyjęcia, że, po pierwsze, sprowadza prawo do funkcji czysto technicznej, po drugie - niweluje pojęcie polityczności, po trzecie-przedstawia prawo jako absolutnie obiektywny, zamknięty system, który opisuje skończony świat. Prawo zatem pozostaje bezsilne wobec tych wydarzeń, których przewidzieć nie można: liberalny pozytywizm odrzuca przecież przekonanie, że w tym zamkniętym systemie luki nie tyle już mogą być, ile - że luki, na skutek nieprzewidzianych zdarzeń, mogą się wykluć. Ruguje istnienie instytucji takiej, jak Arystotelesowska epiekeia z V księgi „Etyki nikomachejskiej”, której rolą było korygowanie istniejących unormowań w obliczu prawnych dziur, a która później przerodziła się w rzymską aequitas, ,»drugie prawo«, istniejące obok prawa ścisłego, poprawiające, modyfikujące wymogi stricti iuris, co wiązało sie przede wszystkim z działalnościa pretorów (edykty pretorskie)" 59 . Taką myśl Schmitt przedstawia po raz pierwszy w pracy, która rozpoczyna pierwszy z dwóch okresów jego przedwojennego namysłu intelektualnego: wydanej w roku 1921 „Dyktaturze”, którą opublikował jako świeżo mianowany profesor prawa publicznego na uniwersytecie w Greifswaldzie. „Dyktatura” to pierwszy tekst Schmitta, który zwiastuje jego zainteresowanie tematem, z którego analizy będzie później najbardziej znany - kwestią stanu wyjątkowego. Według Johna McCormicka sposób, w jaki Schmitt niektóre wcielenia dyktatury interpretuje, pokazuje, z jak nieuformowanym jeszcze myślicielem mamy do czynienia; choć myśliciel z Plettenbergu jest już w kilka lat po publikacji eseju na temat Däublera, potrafi jeszcze o technice pisać przychylnie na przykład wtedy, kiedy rzymską dyktaturę komisaryczną (wynikającą z aequitas) nazywa trafnym połączeniem polityczności i technologii ${ }^{60}$.

Pozytywizm i hegemonia myślenia liberalnego w zachodniej Europie jest w pracy z 1921 r. jednym z głównych celów ataku trzydziestoparoletniego Schmitta: właśnie tę hegemonię, którą określa jako ,atmosferę prawno-liberalnej podejrzliwości wobec dyktatury" ${ }^{\prime \prime}$, obwinia o to, że tytułowa instytucja została wyrugowana $\mathrm{z}$ debaty publicznej i utożsamiona $\mathrm{z}$ despotiami takimi, jak bonapartyzm czy cezaryzm. Do debaty pojęcie jednak powróciło, a to za sprawą rewolucji bolszewickiej i koncepcji dyktatury proletariatu. Schmitt w swojej pracy wywodzi dyktaturę z łacińskiego sformułowania: dictator est qui dicta, dyktatorem jest

${ }^{59}$ W. Dziedziak, Stuszność jako wartość prawa, „Studia Iuridica Lublinensia” 2011, t. 15, s. 72.

${ }^{60}$ Por.: J. McCormick, Carl Schmitt's Critique of Liberalism..., op.cit., s. 135-137; G. Balakrishnan, The Enemy, op.cit., s. 53.

${ }^{61}$ C. Schmitt, Dyktatura. Od źródel nowożytnej idei suwerenności do proletariackiej walki klas, przeł. K. Wudarska, Warszawa 2016, s. 94. 
ten, kto dyktuje wydawane przez siebie zarządzenia - a dyktuje je, w imię wewnętrznej dialektyki dyktatury, w celu zniesienia sytuacji, w której inna forma rządów jest niemożliwa ${ }^{62}$. Dyktatura jako taka jest nie do pomyślenia w ustroju liberalnego państwa ustawodawczego, w którym jedynym obowiązującym prawem jest prawo pozytywne - ono bowiem zakłada, że sytuacja, w której inna forma rządów aniżeli założona przez ustalone już normy nie może mieć miejsca. Radykalną inkarnacją takiego sposobu myślenia jest pozytywistyczne przekonanie o nienaruszalności konstytucji, zgodnie z którym konstytucja oznacza wszystkie i każdy z osobna jej artykuł, co oznacza ograniczenie rozumienia pojęcia „konstytucja" do spisanej ustawy.

Do roztrząsania tego tematu wrócimy niżej; teraz zajmijmy się sposobem, w jaki Schmitt rozumuje o stanie wyjątkowym na gruncie czysto pozytywnym. $\mathrm{O}$ ile bowiem wielu niemieckich prawników tamtego czasu - także pozytywistów, takich jak Gerhard Anschütz - dopuszczało zmianę uchwalonej w 1919 roku konstytucji republiki weimarskiej jako zwykłej ustawy, Schmitt w „Nauce o konstytucji” obstaje przy ograniczeniu możliwości tej zmiany ${ }^{63}$. Jego odpowiedź na polityczny chaos ostatnich lat republiki weimarskiej - partyjne rozbicie, rosnące zagrożenie ze strony ruchów komunistycznych i faszystowskich - jest odpowiedzią stricte legalistyczną. Myśliciel z Plettenbergu chce znaleźć rozwiązanie kryzysu na gruncie prawnych uwarunkowań zaproponowanych przez ustawę zasadniczą, konkretnie zaś - na gruncie uwarunkowań dotyczących stanu wyjątkowego.

W tym miejscu należy uczynić krótki ekskurs na temat tego, jak instytucja stanu wyjątkowego kształtowała się w niemieckich konstytucjach. Jej historycznemu rysowi Schmitt przypatruje się w „Dyktaturze”, zauważając, że popularność wojskowego stanu wyjątkowego w przeszłości Niemiec może stanowić wyłom w europejskiej zasadzie państwa prawa ${ }^{64}$. W istocie, stan wyjątkowy w swoim wojskowym wydaniu był, przypomina Gopal Balakrishnan, silnie obecny i w konstytucji cesarskiej z 1871 roku, której artykuł 68 dawał cesarzowi prawo nie tylko do wypowiedzenia wojny, ale też do wprowadzania stanu wyjątkowego - jako głównodowodzącemu wojska - jak również w pruskim prawie dotyczącym stanu wyjątkowego z roku 1851 (odpowiedzi na polityczny kryzys lat 1848-1849), wedle którego w razie wydarzeń noszących znamiona stanu wyjątkowego lokalną władzę nad administracją i sądownictwem przejmował oficer wojskowy o najwyższym stopniu: „miał prawo zawiesić podstawowe prawa, wydawać dekrety, powoływać specjalne sądy karne" ${ }^{\prime 65}$. W porównaniu do wyżej wymienionych, unormowanie

${ }^{62}$ Ibidem, s. 52.

${ }^{63}$ C. Schmitt, Nauka o konstytucji, op.cit., s. 145; zob. także: E. Kennedy, Constitutional Failure: Carl Schmitt in Weimar, London 2004, s. 20-25.

${ }^{64}$ Idem, Dyktatura, op.cit., s. 18.

${ }^{65}$ G. Balakrishnan, The Enemy, op.cit., s. 29-30. 
stanu wyjątkowego w konstytucji republiki weimarskiej z roku 1919 było zastanawiająco ogólne. Zawarte zostało w art. 48, mającym, jak zauważył na bieżąco międzywojenny polski prawnik Konstanty Grzybowski, charakter drugorzędny ${ }^{66}$. Artykuł ten upoważniał prezydenta Rzeszy do działania w sytuacji „poważnego naruszenia zagrożenia publicznego bezpieczeństwa i porządku w Rzeszy Niemieckiej”. Prezydent mógł wówczas „poczynić konieczne zarządzenia w celu przywrócenia publicznego bezpieczeństwa i porządku, a w razie potrzeby uciec się do siły zbrojnej”"67. Mógł też zawiesić zupełnie lub częściowo prawa zasadnicze, ustanowione w art. 114, 115, 117, 118, 123, 124 i 153 konstytucji (wymienione artykuły dotyczą praw i wolności obywatelskich, ale też wolności zakładania i działania partii politycznych). Jak zauważa Krzysztof Prokop, w porównaniu do stanu wojennego konstytucji cesarskiej z 1851 roku, nie tylko prerogatywy prezydenta były nikłe; w przeciwieństwie do cesarza, ponosił on odpowiedzialność konstytucyjną przed Najwyższym Trybunałem Państwowym i polityczną, przed Reichstagiem ${ }^{68}$. Ustęp piaty artykułu 48 przewidywał ponadto konieczność uchwalenia ustawy szczegółowej, która dokładniej dookreślałaby kompetencje prezydenta. Ta jednak nigdy nie została uchwalona.

To zaś pozwoliło chcącemu odnaleźć sposób na zapanowanie nad politycznym chaosem w republice weimarskiej Schmittowi interpretować go rozszerzająco. W pisanym w roku 1922 (kiedy był profesorem prawa publicznego na uniwersytecie w Bonn) komentarzu do artykułu 48 - jak twierdzi Reinhard Mehring, odpowiedzi na komentarz autorstwa pozytywisty Gerharda Anschütza ${ }^{69}-$ Schmitt argumentuje, iż skoro w ramach ochrony bezpieczeństwa i porządku publicznego suweren - w tym wypadku prezydent - może zawiesić konstytucyjną gwarancję obywatelskich praw i wolności, kategoria porządku jest w zamierzeniu ustawodawcy o wiele istotniejszą dla państwowej konstrukcji aniżeli kategoria praw i wolności. Tu jednakowoż pojawiają się dwa pytania. Pierwsze jako zarzut wobec Schmitta sformułował współczesny mu Karl Löwith, twierdząc, że myślenie na temat stanu wyjątkowego, jakie proponuje filozof z Plettenbergu, jest okazjonalistyczne, ponieważ brakuje w nim rozgraniczenia kryteriów, które trwale i bez analizy aktualnych warunków odróżniałyby stan wyjątkowy od zamachu stanu ${ }^{70}$. Drugie brzmi: jakie właściwie prawo obowiązuje podczas trwania stanu wyjątko-

${ }^{66}$ Zob.: K. Grzybowski, Dyktatura prezydenta Rzeszy. Studjum nad art. 48 ust. II Konstytucji Weimarskiej i rozwojem państwa autorytatywnego w Niemczech, Kraków 1934, s. 6.

${ }^{67}$ Konstytucja Rzeszy, [w:] J. Makowski (red.), Nowe konstytucje, Warszawa 1925, s. 359.

${ }^{68}$ K. Prokop, Stany nadzwyczajne w Konstytucji Rzeczypospolitej Polskiej, Białystok 2005, s. 224

${ }^{69}$ R. Mehring, Carl Schmitt..., op.cit., s. 164-165.

${ }^{70}$ Zob.: H. Falk, The „Theological Nihilism” of Friedrich Gogarten. On a Context in Karl Löwith's Critique of Carl Schmitt, „European Review” 2014, nr 2 (22), s. 218. 
wego? Czy mamy w tej instytucji do czynienia z czasem zupełnie anomicznym, czy przeciwnie?

Na te pytania można znaleźć odpowiedź tylko wtedy, gdy chcemy na nie odpowiedzieć $\mathrm{w}$ duchu, $\mathrm{w}$ jakim zostały postawione - czyli liberalnym. W tym samym roku, w którym Schmitt publikuje swoją analizę artykułu 28 konstytucji republiki weimarskiej, ukazuje się jego „Teologia polityczna”, rozpoczynająca się zdaniem, które stało się schmittiańskim szlagwortem: „Suwerenny jest ten, kto decyduje o stanie wyjątkowym". Stan wyjątkowy z tej filozoficznej pracy Schmitta nie jest tym samym stanem wyjątkowym, o którym czytaliśmy w analizie artykułu 48; jako Ausnahmezustand, pozostaje „stanem bez nazwy”. Według Schmitta, twierdzącego, że wszystkie pojęcia polityczne są zsekularyzowanymi pojęciami teologicznymi, „stanowi bez nazwy” odpowiada teologiczny cud, którym Bóg bezpośrednio działa na świat, nie naruszając jednakże jego porządku ${ }^{71}$. Cudu - podobnie jak wyjątku - nie sposób przewidzieć, i nie sposób przewidzieć, jak świat będzie wyglądał po jego zaistnieniu. Nie sposób go też przed zaistnieniem nazwać, bo nie sposób sobie wyobrazić, jaką postać przybierze. Cud jest tym, czego paradygmat liberalnego państwa ustawodawczego nie jest $\mathrm{w}$ stanie przyjąć do wiadomości: wejściem w świat opisany prawem pozytywnym tego, czego prawo pozytywne nie może przewidzieć.

\section{SCHMITTA KRYTYKA POZYTYWIZMU (II): SCHMITT I NORMATYWIZM HANSA KELSENA}

Cud to jednak perspektywa teologiczna. Jak odrzucić zarzut okazjonalizmu na poziomie prawniczym i politycznym, skoro - pisze Michael G. Salter - „dla Schmitta prawo nie jest czymś zastanym i aktualne znaczenie danej normy zależy dla niego od aktualnie rozgrywających się historycznych, instytucjonalnych i ideologicznych procesów i praktyk" "72? Krytyczny wobec myśliciela z Plettenbergu Hasso Hofmann nazywa nawet wypracowaną przezeń koncepcję prawa i jurysprudencji sytuacyjną i legitymizowaną wyłącznie przez efektywność określonych działań: dane działanie jest prawomocne, jeżeli ma polityczną doniosłość i sprawczość, działający zaś nie musi nawet szukać dla niego pozytywnego prawnego oparcia ${ }^{73}$. O ile takie stwierdzenie jest uprawnione w stosunku do młodego Schmitta (na przykład Schmitta z roku 1914, który w eseju pt. „Dlaczego nie jestem legitymi-

\footnotetext{
71 C. Schmitt, Teologia polityczna, op.cit., s. 59.

72 M.G. Salter, Carl Schmitt. Law as Politics, Ideology and Strategic Myth, op.cit., s. 94.

73 Zob.: M. Croce, A. Salvatore, The Legal Theory of Carl Schmitt, op.cit., s. 148.
} 
stą" uznawał prawo za „rezultat określonego układu sił"74), o tyle w stosunku do Schmitta, który dostrzegł zagrożenia ze strony religijnego traktowania techniki i kryzysu liberalnego państwa ustawodawczego - już nie. Gdyby było, Schmitt niczym by się nie różnił od afirmujących pojęcie chance; można nawet powiedzieć, że sam stałby się pozytywistą, wyznającym typ „myślenia w naukach prawnych (...) [który] podporządkowuje się rozstrzygnięciu każdorazowego znajdującego się u władzy ustawodawcy, ponieważ tylko on może rzeczywiście wymusić realizację"75. By zrozumieć Schmitta krytykę normatywizmu i jego czołowego przedstawiciela - Hansa Kelsena - należy najpierw opisać ich odmienne rozumienie tego, czym jest porządek konstytucyjny.

Schmittiańskie rozwinęło się na przełomie lat 20. i 30., a jego wyrazem są dwie napisane wówczas i cytowane już prace - „Nauka o konstytucji” z 1929 r. i „Legalność i prawomocność” z roku 1932. Na początku tej pierwszej Schmitt zajmuje się różnymi znaczeniami terminu „konstytucja”, wyszczególniając cztery. Po pierwsze - konstytucja oznaczać może dlań ogólną kondycję jedności politycznej i porządku społecznego państwa, zasady spajające państwo w ową jedność $\mathrm{i}$ istnienie instytucji rozstrzygającej spory. „Wtedy - pisze - słowo to nie oznacza systemu czy szeregu przepisów prawnych czy norm, które regulują proces tworzenia się woli politycznej $\mathrm{w}$ państwie czy wykonywanie należących do niego zadań, ale określa właściwie to konkretne, pojedyncze państwo"76. Państwo nie posiada konstytucji, ale nią jest. Schmitt odwołuje się tu do starożytnego, greckiego rozumienia tego terminu, którego najlepszą bodaj definicję podał Izokrates: konstytucja to dusza państwa. Po drugie - konstytucja oznaczać może szczególny, określony rodzaj panującego w państwie porządku: „szczególną formę władzy, przynależną każdemu państwu i nieoderwalną od jego politycznego istnienia"77. Po trzecie - konstytucja to sama spisana ustawa konstytucyjna. Czwarty rodzaj idzie w poprzek takiemu statycznemu rozumieniu tej instytucji i ujmuje konstytucję jako zasadę „dynamicznego stawania się jedności politycznej”. Państwo nie jest w niej pomyślane jako coś założonego z góry, ale jako coś, co „nieustannie powstaje od nowa. Jedność polityczną trzeba codziennie tworzyć, godząc różne przeciwstawne interesy, poglądy i dążenia"78. Właśnie owo rozróżnienie - na trzy typy statyczne i czwarty, dynamiczny - jest dla Schmittiańskiegomyślenia o porządku konstytucyjnym kluczowe i ono znajduje rozwinięcie w późniejszej o trzy lata „Legalności i prawomocności”. Zanim jednak do niej przejdziemy, spójrzmy,

${ }^{74}$ C. Schmitt, Dlaczego nie jestem legitymista?? Rzecz o prawie i sile, przeł. A. Wielomski, „Pro Fide Rege et Lege" 2010, nr 1, s. 43.

${ }^{75}$ Idem, O trzech rodzajach myślenia w nauce prawa, op.cit., s. 98.

${ }^{76}$ Idem, Nauka o konstytucji, op.cit., s. 26-27.

77 Ibidem, s. 28.

${ }^{78}$ Ibidem, s. 29-30. 
jak porządek konstytucyjny ujmują normatywiści, a konkretnie - austriacki prawnik Hans Kelsen.

U fundamentów koncepcji Kelsena stoi kantowskie oddzielenie porządku Sein - tego, jak jest - od porządku Sollen - tego, jak powinno być. Prawo, rozumuje Kelsen za XIX-wiecznym pozytywistą Paulem Labandem, przynależy do tego drugiego. O ile w statycznym porządku Sein normy łączą się ze sobą na podstawie wynikania jednej z drugiej, w przypadku Sollen spoiwem systemu jest ich szczególny rodzaj: normy kompetencyjne. System prawny ma strukturę piramidy: „norma N1 obowiązuje, gdy wskazać można normę wyższego rzędu N2 zawierającą kompetencję do jej ustanowienia. U samego dołu piramidy znajdują sięnormy indywidualne i konkretne, które nie są juz nośnikiem kompetencji prawotwórczych, lecz konkretnych powinności wyrażonych w formie nakazów lub zakazów kierowanych do podmiotów prawa"79. Prawo, według Kelsena, jest prawem o tyle, o ile pod względem formalnym (sposobu ustanawiania) i materialnym (treści) jest zgodne z Grundnorm: normą podstawową, z której wynikają wszelkie inne. Ta, jak zauważa Andreas Kalyvas, u Kelsena funkcjonowała ona jako logiczna presupozycja własnego obowiązywania, rodzaj „opowieści o fundamentach systemu prawa" ${ }^{80}$. Nie wynika ona z żadnej innej i jako "pierwsza konstytucja” stanowi non plus ultra całego systemu prawnego ${ }^{81}$. Nie jest przy tym, według austriackiego prawnika, elementem prawnego systemu na takich zasadach, na jakich jego elementami są inne normy kompetencyjne, lecz jest po prostu transcendentalno-logicznym założeniem. I, co najważniejsze, jest pozbawiona treści jakiejkolwiek oprócz tej, wedle której stanowi kompetencję do wydawania norm konstytucyjnych. „(...) jako formalny punkt odniesienia umożliwia pozytywizację prawa, poczynając od pierwszej historycznej konstytucji, którą według Kelsena ma każde państwo. Po tej historycznie pierwszej konstytucji może następować dowolna liczba kolejnych" ${ }^{\prime 2}$.

Schmitt, rozwijając w „Legalności i prawomocności” koncepcje z „Nauki o konstytucji”, rozumuje inaczej. Kontynuując podział konstytucji na statyczne i dynamiczne, tworzy w pracy tej jeszcze jedno rozróżnienie: na konstytucję (Verfassung) i ustawę konstytucyjną (Verfassunggesetz). Ta druga jest po prostu spisaną ustawą, szeregiem przepisów prawa pozytywnego, których obowiązywanie

${ }^{79}$ K. Koźmiński, K. Kaleta, Charakter władzy suwerennej w koncepcjach ładu konstytucyjnego Hansa Kelsena i Carla Schmitta, „Filozofia Publiczna i Edukacja Demokratyczna” 2013, nr 2, s. 157.

${ }^{80}$ A. Kalyvas, Democracy and the Politics of the Extraordinary: Max Weber, Carl Schmitt and Hannah Arendt, Cambridge 2008, s. 129.

${ }^{81}$ G. Balakrishnan, The Enemy, op.cit., s. 93.

${ }^{82}$ H. Schambeck, Nauka prawa Hansa Kelsena, „Studia Iuridica Toruniensia” 2011, t. VIII, s. $37-38$. 
opiera się na tym, że są legalne - zostały uchwalone w obowiązującym trybie i w obowiązującym trybie ogłoszone.

Tu nagle kończy się powinność i normatywność, w ich miejsce pojawia się tautologia czystej faktyczności: coś obowiązuje, jeżeli obowiązuje i dlatego że obowiązuje. Oto pozytywizm ${ }^{83}$.

Ta pierwsza - to sposób dynamicznego stawania się państwa jako jedności politycznej, która obowiązuje dlatego, że jest prawomocna. Ustawa konstytucyjna może mieć treść dowolną - w końcu w ramach przepisów prawa pozytywnego uchwalić można wszystko i w ten sposób przeprowadzić zamach na ducha prawa danego państwa. Konstytucja - to co innego. Nie jest ona „tylko regułą czy normą, którą się subsumuje" ${ }^{84}$, uchwala i ogłasza, lecz elementem szerszego i dłuższego porządku historycznego i politycznego, a jej prawomocność opiera się właśnie na jej treści. O ile więc w teorii Kelsena „polityczny byt lub też stawanie się jedności porządku państwowego zostają przekształcone w funkcjonowanie"85, które jest beztreściowe $\mathrm{i}$ - po weberowsku - opiera się na działaniu administracji i biurokracji, o tyle w teorii Schmitta ów polityczny byt i stawanie się jedności porządku państwowego są niemożliwe do rozdzielenia od aktualnie panujących warunków politycznych i społecznych. Jego Verfassung jest faktyczne i dynamiczne, i taka też musi być jego odpowiedź na normatywistyczną, mieszczańską jurysprudencję, której „ostatni akord” stanowi nauka Hansa Kelsena ${ }^{86}$.

Teoria Kelsena pozostaje dla liberalnego pozytywizmu o tyle znamienna, że wypracowana w niej norma pierwsza, Grundnorm jest, jako logiczno-jurydyczna fikcja, nie tyle beztreściowa - jest także bezosobowa i funkcjonuje wyłącznie jako nakaz realizacji norm niższych jako ustanowionych zgodnie z wywiedzioną $\mathrm{z}$ niej kompetencją ${ }^{87}$. Włączenie w nią czynnika osobowego, czyli, jak uważał Schmitt, jednostkowego suwerena, który podejmuje decyzję o zaistnieniu konstytucji (a także o zaistnieniu stanu wyjątkowego) jest niemożliwe, ponieważ zainfekowałoby to twardy rozdział pozytywnych norm od prawdziwego życia. Rozdział ten zaś, skupienie właśnie na istniejących, pozytywnych normach, pod względem nauki jurysprudencji likwiduje, jak twierdzi Michael G. Salter „namysł nad samym prawa tworzeniem i jego stosowaniem (i niestosowaniem), nad jego efektywnością i tym, jaki jest jego odbiór. Takie kwestie, związane z socjologią prawa, nie mogą być częścią czystej teorii prawa, ponieważ musi ona respektować

${ }^{83}$ C. Schmitt, Nauka o konstytucji, s. 34. Zob. także: C.H. McIlwain, Constitutionalism, Ancient and Modern, Ithaca 1971, s. 21.

${ }^{84}$ Idem, Teologia polityczna, op.cit., s. 30.

${ }^{85}$ Idem, Nauka o konstytucji, op.cit., s. 32.

${ }^{86}$ Ibidem, s. 33.

${ }^{87}$ H. Kelsen, Foundations of Democracy, „Ethics” 1955, vol. 66, s. 38. 
rozróżnienie między tym, co normatywne, a tym, co empiryczne"88. W efekcie: bez odniesienia do tego, jak law radzi sobie in action i jaka action stała za jego uchwaleniem, prawo staje się aksjologicznie neutralne. Nie można bowiem poddać osądowi z punktu widzenia aksjologii (czy to moralnej, na którą nie zgodziłby się Schmitt, czy to politycznej) przepisu bez odniesienia do tego, jak jest aplikowany.

W teorii Kelsena, twierdzi myśliciel z Plettenbergu (i, paradoksalnie, jest to punkt, w którym Kelsen i Schmitt zdają się spotykać), to nie państwo jest dynamiczną konstytucją - to konstytucja jest państwem. O ile więc Schmitt aktualną mu, dynamiczną rzeczywistość polityczną ujmuje jako konstytucję i nie oddziela jej od porządku prawnego, lecz bada, jak na gruncie tego porządku i rzeczywistości można doprowadzić do zmiany (jak czynił to w wypadku konstytucji republiki weimarskiej), o tyle Kelsen, zdając się nie dostrzegać problematyki aktualnej gry politycznej i partyjnej, rzeczywistość traktuje jako jednocześnie Sein i Sollen, ponieważ uważa, że państwo nie może nie być państwem prawa. „Wszelka - pisze - nauka o państwie jest możliwa jedynie jako nauka o prawie państwowym, a każde prawo jest prawem państwowym, ponieważ każde państwo jest państwem prawa" ${ }^{" 89}$. Kelsen twierdzi, że państwo pozbawione prawa jest konceptualnie niemożliwe i uznaje je za normę, której nie da się przeciwstawiać innej. To, należy nadmienić, stwierdzenie stojące w poprzek ówczesnego niemieckiego pozytywizmu, na przykład dualistycznej koncepcji Georga Jellinka, wedle której państwo to fakt polityczny, będący gwarantem egzekwowania prawa. Jellinek pojmował państwo jednocześnie jako stowarzyszenie ludzi i system norm, dla Kelsena ludzie nie mają większego znaczenia. W jego koncepcji polityczna suwerenność nie wiąże się z żadnym komponentem osobowym: suwerenem nie może być (a przynajmniej nie pierwotnie) lud, ponieważ istnienie państwa jest warunkowane prawem, a lud polityczny (czyli: grupa osób zawiązana we wspólnotę o politycznym celu) istnieć bez państwa nie może. Gdyby państwo od prawa oddzielić, jego rządy zostałyby istotnie ograniczone.

Oczywiście, prawo można zmieniać, jednak zmiana ta musi być kontrolowana. Tu Kelsen wprowadza element osobowy, twierdząc, że instytucją kontrolującą tę zmianę powinien być sąd konstytucyjny. Z instytucją sądownictwa konstytucyjnego wiąże się kolejny wątek sporu Schmitta z dostrzegającym problem słabości legislatywy w Republice Weimarskiej i w ówczesnej, przedanszlusowej Austrii Kelsenem: austriacki prawnik pragnął bowiem, by to właśnie nowy, powołany w 1920 r. sąd konstytucyjny posiadał nadzwyczajne uprawnienia, które pozwoliłyby mu poradzić sobie z politycznym chaosem bez przekraczania przy

\footnotetext{
${ }^{88}$ M.G. Salter, Carl Schmitt. Law as Politics, Ideology and Strategic Myth, op.cit., s. 109.

${ }^{89}$ H. Kelsen, God and the State, „Logos” 1922, nr 11 (23), s. 63.
} 
tym obowiązujących przepisów prawnych. Sąd taki był dlań podporą demokracji, która, twierdzi Kelsen, „bez kontroli jest w dłuższej perspektywie niemożliwa, poniechanie bowiem tego samoograniczenia, jakim jest zasada legalności, równoznaczne jest z samobójstwem demokracji" ${ }^{90}$. Co najistotniejsze, uznaje Kelsen, iż decyzje wydawane przez takie ciało nie mają charakteru politycznego. „Władza sądownicza - pisze bowiem Kelsen - posiada ten sam »polityczny« charakter, który odnajdujemy w ustawodawstwie. Istnieje tylko różnica ilościowa, nie zaś jakościowa”. Kelsen traktuje zatem trybunał jako ustawodawcę negatywnego, który rozstrzygać może tylko na gruncie wynikającej z Grundnorm konstytucji, nie posiada zaś własnej inicjatywy legislacyjnej ${ }^{11}$.

Schmitt, domagający się, by przy okazji stanu wyjątkowego ekstraordynardyjne uprawnienia znalazły się w rękach egzekutywy (czyli prezydenta Rzeszy) taką koncepcję uważa za szkodliwą, bowiem umieszczającą władzę polityczną w rękach ciała, które, w świetle koncepcji trójpodziału władz, nie powinno jej posiadać. Twierdzi, że „trybunał, który powstał z pomysłu Kelsena, był ciałem autodestrukcyjnym: legislaturą w przebraniu, która nie miała nic wspólnego z władzą sądowniczą, ulegającym wpływom partii politycznych"92. Jednocześnie raził go kolegialny charakter tej instytucji, wobec którego miał podobne obiekcje, co w stosunku do parlamentu w wydaniu liberalnym; dla niego istotą parlamentu była „nadzieja, że decydujące rozstrzygnięcie, krwawą ostateczną bitwę można przekształcić w debatę, odroczyć na zawsze dzięki niekończącej się dyskusji”"93. Proponując prezydenta jako strażnika konstytucji w zamian za trybunał, Schmitt opierał się na trzech argumentach. Po pierwsze, uważał że prezydent jako organ jednostkowy może szybciej niż kolegialny Trybunał podjąc decyzję dotyczącą konstytucyjności danego aktu. Po drugie, taka decyzja jest - jak każda decyzja tego, który jest suwerenny - decyzją polityczną, nie zaś prawną, i dlatego powinien ją podejmować ten, kto posiada do tego rodzaju decyzji legitymizację (przez bycie przedstawicielem narodu). Po trzecie, Schmitt zauważa, że tylko polityczna decyzja może w istocie konstytucji (jako normy) bronić: obrona normy przez normę jest, według niego, niemożliwa.

${ }^{90}$ Idem, The Essence and Value of Democracy, przeł. N. Urbinati, B. Graff, red. C. Accetti, New York 2013, s. 83.

${ }^{91}$ Idem, Who ought to be the Guardian of the Constitution, [w:] L. Vinx (red.), The Guardian of the Constitution: Hans Kelsen and Carl Schmitt on the Limits of Constitutional Law, Cambridge 2015, s. 184.

${ }_{92}$ Wykład prof. A.L. Pergoli, otwierający seminarium Komisji Weneckiej „The role of the constitutional court in the consolidation of the rule of law" w Bukareszcie, 9 lipca 1994 r., http:// www.venice.coe.int/webforms/documents/default.aspx?pdffile=CDL-STD(1994)010-e [dostęp: 15.03.2017].

${ }_{93}$ C. Schmitt, Teologia polityczna, op.cit., s. 63. 
Dla normatywistycznej czy formalistycznej logiki problem ten w ogóle nie istnieje, skoro wyższy stopień obowiązywania nie może być zagrożony czy podważony przez niższy - pisze zaś formalistyczne prawo konstytucyjne kończy się tam, gdzie zaczynają się prawdziwe problemy ${ }^{94}$.

Przez te ostatnie rozumie Schmitt moment wejścia w życie państwa rzeczywistości, która nie została poddana normowaniu i, żeby ją przezwyciężyć, trzeba działań z porządku, który nie znajduje swojego uprawomocnienia w prawie.

W krytyce Kelsenowskiego trybunału można oczywiście dostrzec cień opisywanej wyżej, Schmitta krytyki utożsamienia polityczności z działalnością partii politycznych; ale też cień czegoś innego. Krytykujący liberalny normatywizm Schmitt zarzuca mu traktowanie prawa i rzeczywistości jako perpetuum mobile: decyzja bezosobowego prawodawcy, raz wydana, wprawia w ruch cały system ${ }^{95}$. W takim sposobie myślenia kryzys zagrażający jedności politycznej państwa jest niczym więcej, jak tylko wypadkiem przy pracy i daje się rozwiązać przy pomocy instrumentów, jakimi są traktowane czysto technicznie normy ${ }^{96}$. Schmitt uważa inaczej: nie deprecjonuje ważności pozytywnych norm, ale twierdzi, że aby ukonstytuować lub też przywrócić stan, w którym mogą one funkcjonować, należy je naprzód - w formie stanu wyjątkowego - podważyć. Podważyć można zaś normy wszystkie oprócz podstawowych, które tworzą polityczne rozstrzygnięcie suwerena (w przypadku konstytucji weimarskiej: narodu niemieckiego), których substancją jest konstytucja. Jak pisze Paweł Kaczorowski, „są one niezmienne, gdyż wyrażają tożsamość stojącego za nimi podmiotu konstytuującego, są niezmienne gdyż stanowią fundament konstytucji i łączą składające się na nią normy z rzeczywistością polityczną"

Kelsen rozumował odmiennie. Jego teoria konstytucyjna przyjmuje Grundnorm jedynie jako logiczne założenie: neguje zatem istnienie wyższej woli, która nadawałaby politycznym konstytucyjnym rozstrzygnięciom prawomocność. Nie interesuje Kelsena, w jakich warunkach kształtuje się treść norm konstytucyjnych. Filozoficzną podstawę dla liberalnej demokracji w jego rozumieniu stanowi etyczny relatywizm, zasadzający się na beztreściowości Grundnorm $^{98}$. On jest

${ }^{94}$ Idem, The Guardian of the Constitution, [w:] The Guardian of the Constitution: Hans Kelsen and Carl Schmitt on the Limits of Constitutional Law, op. cit., s. 145.

${ }_{95}$ Zob.: J.P. McCormick, Irracjonalny wybór i krwawa walka. Wprowadzenie do teorii Carla Schmitta, przeł. A. Warso, „Kronos” 2008, nr 3, s. 81.

96 Zob.: A. Croce, M. Salvatore, The Legal Theory of Carl Schmitt, op.cit., s. 136.

${ }_{97}$ P. Kaczorowski, Carl Schmitt, jego nauka o konstytucji i kwestia suwerena-ustrojodawcy, „Teologia Polityczna”, 30.05.2016, http://www.teologiapolityczna.pl/prof-pawel-kaczorowski-carl-schmitt-jego-nauka-o-konstytucji-i-kwestia-suwerena-ustrojodawcy-tpct-9-/Wydrukuj [dostęp: 15.03. 2017].

${ }_{98}$ H. Kelsen, Foundations of Democracy, „Ethics” 1955, vol. 66, s. 38-39. 
największą słabością normatywistycznej koncepcji Kelsena - jako ostatecznego spełnienia pozytywizmu - ponieważ o ile Schmittiański decyzjonizm to, jak pisał Ryszard Skarzyński, teoria, która uzasadnia zarówno dyktaturę, jak i demokrację, uzasadniający głównie demokrację normatywizm Kelsena prowadzi do jej rozmycia i osłabienia państwa ${ }^{99}$.

\section{PODSUMOWANIE}

Schmittiańska krytyka liberalizmu zasadza się na paradoksie. Chociaż ten nurt polityczno-ideowy jest przedmiotem rozlicznych anatem myśliciela z Plettenbergu, takie jego prace, jak analiza art. 48 konstytucji republiki weimarskiej zdają się bronić politycznych uwarunkowań, w których zaistniał. Starając się liberalizm skrytykować, Schmitt używa argumentów, które są z natury liberalne - na przykład wówczas, gdy twierdzi, że liberalizm prowadzi do państwa totalnego, które ogranicza to, co jest dla liberalizmu najważniejsze: wolność jednostki. Paradoksalność tej krytyki rozjaśnia uwaga Benjamina Schupmanna, w myśl której Schmitt nie krytykował liberalizmu samego w sobie, lecz przekonanie sobie współczesnych liberałów, iż wyznawana przez nich ideologia nie jest nurtem politycznym. Namawiał więc ich, by stali się ,politycznymi liberałami. Zaangażować się - jak pisze Schupmann - pod względem politycznym w liberalizm znaczyło dlań powziąć działanie przeciwko egzystencjalnym zagrożeniom dla samych fundamentów porządku państwowego, by mógł pozostać stabilnym w czasie"100. Polityczne zaangażowanie i uznanie samych siebie za przedstawicieli nurtu politycznego miałoby, wedle tezy Schupmanna, doprowadzić do końca postrzegania liberałów jako działających w sferze niepoddających się dyskusji aksjomatów o czym Schmitt pisał w „Tyranii wartości” - lecz politycznych interesów, które nie mają charakteru uniwersalistycznego. Przykładem takiego uniwersalizmu zdaje się dla Schmitta być właśnie myśl Kelsena, który pod pozorem tworzenia niezależnego sądu konstytucyjnego w Austrii starał się przemycić swoje liberalne poglądy jako obowiązujące obiektywnie.

Zaznaczony wyżej paradoks sprawia, iż zdaje się, iż liberalizm w latach 10 . i 20. służy Carlowi Schmittowi za parasol, zbierający krytyki kilku innych kwestii: religijnego traktowania techniki (a wcześniej gospodarki i ekonomii w rozumieniu Wirtschaft), neutralizacji polityczności, oddzielenia prawa od prawdziwego życia i beztreściowości Grundnorm. Niewątpliwym problemem jego krytyki $\mathrm{w}$ tamtym czasie jest też brak pozytywnej odpowiedzi na pytanie: co zamiast libe-

${ }_{99}$ Zob.: R. Skarzyński, Od chaosu do tadu. Carl Schmitt i problem tego, co polityczne, Warszawa 1991, s. 14.

100 B. Schupmann, Carl Schmitt's State and Constitutional Theory, Oxford 2018, s. 216. 
ralizmu? Jak zauważa John McCormick, teoria Schmitta jest stricte polemiczna: nie podejmuje żadnego całościowego, pozytywnego programu, który mógłby liberalizm zastąić ${ }^{101}$. W późniejszych latach, kiedy Schmitt zainteresował się francuskim i włoskim instytucjonalizmem, taki program się pojawił. To jednak temat na osobną pracę.

\section{CARL SCHMITT'S CRITIQUE OF LIBERALISM BETWEEN 1916 AND 1938. AN ATTEMPT AT SYNTHESIS AND INTERPRETATION}

\section{Summary}

The article is an analysis of the critique of liberalism conducted by Carl Schmitt, a German law philosopher and political theorist, in his written works created before 1939. He treated liberalism as a political philosophy, a system of state governance, and a legal system, i.e. liberalism which stems from positivism. The paper concentrates on examining the aforementioned critique starting from Schmitt's first works (namely, philological analyses), through Schmitt's critique of the Weimar Republic's Constitution from 1919, and ending with the dispute between the thinker from Plettenberg and Hans Kelsen. Moreover, the article attempts to show certain permanent elements of Schmitt's critique (accentuating the influence of technological growth on the political process) as well as those which changed with time (Schmitt's attitude towards Hobbes as the father of liberalism as well as his deliberations on the neutralization of the public sphere). The paper is complemented by an analysis of a positive - at least in a certain way - remedy for liberalism which was created by Schmitt, namely, the Theory of the State of Exception. In the first place, it is analyzed on the basis of Article 48 of the Constitution of the Weimar Republic. And secondly, it is analyzed as a secularized theological term of "State without a Name".

\section{CRITIQUE DU LIBERALISME PAR CARL SCHMITT, PENDANT LES ANNEES 1916-1938. TENTATIVE DE SYNTHESE ET D'INTERPRETATION}

\section{Resumé}

L'article analyse les critiques que ce philosophe allemand du droit et théoricien de la politique adressait dans ses œuvres écrites avant 1939 au libéralisme - entendu comme la philosophie politique, le système de gouvernement de l'État ainsi que le système juridique, c'est-à-dire le positivisme issu du libéralisme. L'auteur de l'article cherche à retracer cette critique depuis les premiers travaux de Schmitt en tant qu'analyses philologiques, à travers la critique schmittienne de la constitution de la République de Weimar de 1919, jusqu'à un controverse entre le penseur de Plettenberg et Hans Kelsen; il tente de montrer quelques éléments stables de la critique de Schmitt (l’impact du développement technologique sur le processus politique, la théorie de la zone centrale) ainsi que ceux qui ont chan-

101 J. McCormick, Carl Schmitt's Critique of Liberalism..., op.cit., s. 135. 
gé au fil du temps (l'attitude de Schmitt envers Hobbes en tant que père du libéralisme, sa réflexion sur la neutralisation de la sphère publique). Le texte est complété par l'analyse d'un remède positif - au moins d'une certaine manière - au libéralisme que Schmitt a créé, à savoir la théorie de l'état d'exception, analysé à la lumière de l'art. 48 de la constitution de la République de Weimar - d'une part, et en tant que concept théologique sécularisé d' «état sans nom »-d'autre part. 